\title{
Nanocage-Based In ${ }^{\mathrm{III}}\left\{\mathrm{Tb}^{\mathrm{III}}\right\}_{2}$-Organic Framework Featuring Lotus-Shaped Channels for Highly Efficient $\mathrm{CO}_{2}$ Fixation and $\mathrm{I}_{2}$ \\ Capture
}

Hongtai Chen, ${ }^{\dagger}$ Liming Fan, ${ }^{\dagger}$ Xiutang Zhang, ${ }^{*}+$ and Lufang $M a^{*,+}$

\begin{abstract}
${ }^{\dagger}$ Department of Chemistry, College of Science, North University of China, Taiyuan 030051, People's Republic of China.E-mail: xiutangzhang@163.com.

College of Chemistry and Chemical Engineering, Luoyang Normal University, Luoyang, 471934, China. E-mail: mazhuxp@126.com.
\end{abstract}


Table S1. Crystallographic data and refinement parameters of NUC-5.

\begin{tabular}{|c|c|}
\hline Complex & NUC-5 \\
\hline Formula & $\mathrm{C}_{44} \mathrm{H}_{59} \mathrm{InN}_{2} \mathrm{O}_{23} \mathrm{~Tb}_{2}$ \\
\hline $\mathrm{Mr}$ & 1565.45 \\
\hline Crystal system & Monoclinic \\
\hline Space group & $\mathrm{C} 12 / \mathrm{c} 1$ \\
\hline a ( $(\AA)$ & 18.661(4) \\
\hline $\mathrm{b}(\AA)$ & $23.359(4)$ \\
\hline c $(\AA)$ & $21.359(3)$ \\
\hline$\alpha\left(^{\circ}\right)$ & 90 \\
\hline$\beta\left(^{\circ}\right)$ & $101.962(6)$ \\
\hline$\gamma\left({ }^{\circ}\right)$ & 90 \\
\hline $\mathrm{V}\left(\AA^{3}\right)$ & 9108(3) \\
\hline Z & 4 \\
\hline $\operatorname{Dcalcd}\left(\mathrm{g} \cdot \mathrm{cm}^{-3}\right)$ & 1.142 \\
\hline$\mu\left(\mathrm{mm}^{-1}\right)$ & 1.841 \\
\hline GOF & 1.000 \\
\hline $\mathrm{R}_{1}[\mathrm{I}>2 \sigma(\mathrm{I})] \mathrm{a}$ & 0.0655 \\
\hline$w R_{2}[I>2 \sigma(I)] b$ & 0.2312 \\
\hline$R_{1}$ a(all data) & 0.0754 \\
\hline $\mathrm{w} R_{2}^{\mathrm{b}}$ (all data) & 0.2432 \\
\hline $\begin{array}{l}R_{\text {int }} \\
{ }^{a} R_{1}=\sum|| F_{o}|-| F_{c}|| / \sum \mid F\end{array}$ & $\begin{array}{r}0.0455 \\
\left.w\left(F_{o}^{2}\right)^{2}\right|^{1 / 2}\end{array}$ \\
\hline
\end{tabular}


Table S2. Selected bond lengths and angles of NUC-5.

\begin{tabular}{|c|c|c|c|c|c|}
\hline \multicolumn{6}{|l|}{ NUC-5 } \\
\hline $\mathrm{Tb}(1)-\mathrm{O}(1)$ & $2.287(6)$ & $\mathrm{O}(1)-\mathrm{Tb}(1) \# 3$ & $2.790(7)$ & $\mathrm{O}(9)-\mathrm{Tb}(1) \# 2$ & $2.455(7)$ \\
\hline $\mathrm{Tb}(1)-\mathrm{O}(6) \# 4$ & $2.330(7)$ & $\mathrm{O}(2)-\mathrm{Tb}(1) \# 3$ & $2.368(6)$ & $\mathrm{O}(10)-\mathrm{Tb}(1) \# 2$ & $2.432(7)$ \\
\hline $\mathrm{Tb}(1)-\mathrm{O}(2) \# 3$ & $2.368(6)$ & $\mathrm{Tb}(1)-\mathrm{O}(10) \# 2$ & $2.432(7)$ & $\mathrm{Tb}(1)-\mathrm{O}(8) \# 2$ & $2.487(6)$ \\
\hline $\mathrm{Tb}(1)-\mathrm{O}(5) \# 5$ & $2.377(6)$ & $\mathrm{Tb}(1)-\mathrm{O}(9) \# 2$ & $2.455(7)$ & $\mathrm{Tb}(1)-\mathrm{O}(1) \# 3$ & $2.790(7)$ \\
\hline $\mathrm{Tb}(1)-\mathrm{O}(7) \# 2$ & $2.429(6)$ & $\mathrm{O}(8)-\mathrm{Tb}(1) \# 2$ & $2.487(6)$ & $\mathrm{O}(5)-\mathrm{Tb}(1) \# 8$ & $2.377(6)$ \\
\hline $\mathrm{O}(6)-\mathrm{Tb}(1) \# 9$ & $2.330(7)$ & $\mathrm{O}(7)-\mathrm{Tb}(1) \# 2$ & $2.429(6)$ & & \\
\hline $\operatorname{In}(1)-O(12) \# 1$ & $2.339(9)$ & $\operatorname{In}(1)-\mathrm{O}(11) \# 1$ & $2.334(8)$ & $\mathrm{O}(11)-\operatorname{In}(1) \# 1$ & $2.334(8)$ \\
\hline $\operatorname{In}(1)-O(3)$ & $2.260(12)$ & $\operatorname{In}(1)-O(11) \# 7$ & $2.334(8)$ & $\mathrm{O}(12)-\operatorname{In}(1) \# 1$ & $2.339(9)$ \\
\hline $\operatorname{In}(1)-\mathrm{O}(3) \# 6$ & $2.260(12)$ & $\operatorname{In}(1)-O(12) \# 7$ & $2.339(9)$ & $\operatorname{In}(1)-O(4) \# 6$ & $2.308(10)$ \\
\hline $\operatorname{In}(1)-O(4)$ & $2.308(10)$ & & & & \\
\hline $\mathrm{O}(1)-\mathrm{Tb}(1)-\mathrm{O}(6) \# 4$ & $77.4(2)$ & $\mathrm{O}(1)-\mathrm{Tb}(1)-\mathrm{O}(10) \# 2$ & $83.0(3)$ & $\mathrm{O}(10) \# 2-\mathrm{Tb}(1)-\mathrm{O}(9) \# 2$ & $53.6(3)$ \\
\hline $\mathrm{O}(1)-\mathrm{Tb}(1)-\mathrm{O}(2) \# 3$ & $127.8(2)$ & $\mathrm{O}(6) \# 4-\mathrm{Tb}(1)-\mathrm{O}(10) \# 2$ & $141.3(3)$ & $\mathrm{O}(1)-\mathrm{Tb}(1)-\mathrm{O}(8) \# 2$ & $90.0(2)$ \\
\hline $\mathrm{O}(6) \# 4-\mathrm{Tb}(1)-\mathrm{O}(2) \# 3$ & $79.9(3)$ & $\mathrm{O}(2) \# 3-\mathrm{Tb}(1)-\mathrm{O}(10) \# 2$ & 137.2(3) & $\mathrm{O}(6) \# 4-\mathrm{Tb}(1)-\mathrm{O}(8) \# 2$ & $76.5(2)$ \\
\hline $\mathrm{O}(1)-\mathrm{Tb}(1)-\mathrm{O}(5) \# 5$ & $80.6(2)$ & $\mathrm{O}(5) \# 5-\mathrm{Tb}(1)-\mathrm{O}(10) \# 2$ & $74.4(2)$ & $\mathrm{O}(2) \# 3-\mathrm{Tb}(1)-\mathrm{O}(8) \# 2$ & $128.9(2)$ \\
\hline $\mathrm{O}(6) \# 4-\mathrm{Tb}(1)-\mathrm{O}(5) \# 5$ & $133.1(2)$ & $\mathrm{O}(7) \# 2-\mathrm{Tb}(1)-\mathrm{O}(10) \# 2$ & $99.8(3)$ & $\mathrm{O}(5) \# 5-\mathrm{Tb}(1)-\mathrm{O}(8) \# 2$ & $144.4(2)$ \\
\hline $\mathrm{O}(2) \# 3-\mathrm{Tb}(1)-\mathrm{O}(5) \# 5$ & $81.8(3)$ & $\mathrm{O}(1)-\mathrm{Tb}(1)-\mathrm{O}(9) \# 2$ & $133.6(2)$ & $\mathrm{O}(7) \# 2-\mathrm{Tb}(1)-\mathrm{O}(8) \# 2$ & $53.1(2)$ \\
\hline $\mathrm{O}(1)-\mathrm{Tb}(1)-\mathrm{O}(7) \# 2$ & $137.7(2)$ & $\mathrm{O}(6) \# 4-\mathrm{Tb}(1)-\mathrm{O}(9) \# 2$ & $146.6(2)$ & $\mathrm{O}(10) \# 2-\mathrm{Tb}(1)-\mathrm{O}(8) \# 2$ & $70.3(2)$ \\
\hline $\mathrm{O}(6) \# 4-\mathrm{Tb}(1)-\mathrm{O}(7) \# 2$ & $74.6(2)$ & $\mathrm{O}(2) \# 3-\mathrm{Tb}(1)-\mathrm{O}(9) \# 2$ & $85.7(3)$ & $\mathrm{O}(9) \# 2-\mathrm{Tb}(1)-\mathrm{O}(8) \# 2$ & $89.8(2)$ \\
\hline $\mathrm{O}(2) \# 3-\mathrm{Tb}(1)-\mathrm{O}(7) \# 2$ & $77.2(2)$ & $\mathrm{O}(5) \# 5-\mathrm{Tb}(1)-\mathrm{O}(9) \# 2$ & $73.2(2)$ & $\mathrm{O}(1)-\mathrm{Tb}(1)-\mathrm{O}(1) \# 3$ & $78.3(2)$ \\
\hline $\mathrm{O}(5) \# 5-\mathrm{Tb}(1)-\mathrm{O}(7) \# 2$ & 141.1(2) & $\mathrm{O}(7) \# 2-\mathrm{Tb}(1)-\mathrm{O}(9) \# 2$ & $72.9(2)$ & $\mathrm{O}(6) \# 4-\mathrm{Tb}(1)-\mathrm{O}(1) \# 3$ & $67.4(2)$ \\
\hline $\mathrm{O}(2) \# 3-\mathrm{Tb}(1)-\mathrm{O}(1) \# 3$ & $49.7(2)$ & $\mathrm{O}(6) \# 4-\mathrm{Tb}(1)-\mathrm{O}(5) \# 5$ & $133.1(2)$ & $\mathrm{O}(7) \# 2-\mathrm{Tb}(1)-\mathrm{O}(10) \# 2$ & $99.8(3)$ \\
\hline $\mathrm{O}(5) \# 5-\mathrm{Tb}(1)-\mathrm{O}(1) \# 3$ & $67.9(2)$ & $\mathrm{O}(2) \# 3-\mathrm{Tb}(1)-\mathrm{O}(5) \# 5$ & $81.8(3)$ & $\mathrm{O}(1)-\mathrm{Tb}(1)-\mathrm{O}(9) \# 2$ & $133.6(2)$ \\
\hline $\mathrm{O}(7) \# 2-\mathrm{Tb}(1)-\mathrm{O}(1) \# 3$ & $117.7(2)$ & $\mathrm{O}(1)-\mathrm{Tb}(1)-\mathrm{O}(7) \# 2$ & $137.7(2)$ & $\mathrm{O}(6) \# 4-\mathrm{Tb}(1)-\mathrm{O}(9) \# 2$ & $146.6(2)$ \\
\hline $\mathrm{O}(10) \# 2-\mathrm{Tb}(1)-\mathrm{O}(1) \# 3$ & $140.0(2)$ & $\mathrm{O}(6) \# 4-\mathrm{Tb}(1)-\mathrm{O}(7) \# 2$ & $74.6(2)$ & $\mathrm{O}(2) \# 3-\mathrm{Tb}(1)-\mathrm{O}(9) \# 2$ & $85.7(3)$ \\
\hline $\mathrm{O}(9) \# 2-\mathrm{Tb}(1)-\mathrm{O}(1) \# 3$ & $123.2(2)$ & $\mathrm{O}(2) \# 3-\mathrm{Tb}(1)-\mathrm{O}(7) \# 2$ & $77.2(2)$ & $\mathrm{O}(5) \# 5-\mathrm{Tb}(1)-\mathrm{O}(9) \# 2$ & $73.2(2)$ \\
\hline $\mathrm{O}(8) \# 2-\mathrm{Tb}(1)-\mathrm{O}(1) \# 3$ & $143.6(2)$ & $\mathrm{O}(5) \# 5-\mathrm{Tb}(1)-\mathrm{O}(7) \# 2$ & $141.1(2)$ & $\mathrm{O}(7) \# 2-\mathrm{Tb}(1)-\mathrm{O}(9) \# 2$ & $72.9(2)$ \\
\hline $\mathrm{O}(1)-\mathrm{Tb}(1)-\mathrm{O}(6) \# 4$ & $77.4(2)$ & $\mathrm{O}(1)-\mathrm{Tb}(1)-\mathrm{O}(10) \# 2$ & $83.0(3)$ & $\mathrm{O}(10) \# 2-\mathrm{Tb}(1)-\mathrm{O}(9) \# 2$ & $53.6(3)$ \\
\hline $\mathrm{O}(1)-\mathrm{Tb}(1)-\mathrm{O}(2) \# 3$ & $127.8(2)$ & $\mathrm{O}(6) \# 4-\mathrm{Tb}(1)-\mathrm{O}(10) \# 2$ & $141.3(3)$ & $\mathrm{O}(1)-\mathrm{Tb}(1)-\mathrm{O}(8) \# 2$ & $90.0(2)$ \\
\hline $\mathrm{O}(6) \# 4-\mathrm{Tb}(1)-\mathrm{O}(2) \# 3$ & $79.9(3)$ & $\mathrm{O}(2) \# 3-\mathrm{Tb}(1)-\mathrm{O}(10) \# 2$ & 137.2(3) & $\mathrm{O}(6) \# 4-\mathrm{Tb}(1)-\mathrm{O}(8) \# 2$ & $76.5(2)$ \\
\hline $\mathrm{O}(1)-\mathrm{Tb}(1)-\mathrm{O}(5) \# 5$ & $80.6(2)$ & $\mathrm{O}(5) \# 5-\mathrm{Tb}(1)-\mathrm{O}(10) \# 2$ & $74.4(2)$ & $\mathrm{O}(2) \# 3-\mathrm{Tb}(1)-\mathrm{O}(8) \# 2$ & $128.9(2)$ \\
\hline $\mathrm{O}(5) \# 5-\mathrm{Tb}(1)-\mathrm{O}(8) \# 2$ & $144.4(2)$ & $\mathrm{O}(2) \# 3-\mathrm{Tb}(1)-\mathrm{O}(1) \# 3$ & $49.7(2)$ & $\mathrm{O}(8) \# 2-\mathrm{Tb}(1)-\mathrm{O}(1) \# 3$ & $143.6(2)$ \\
\hline $\mathrm{O}(7) \# 2-\mathrm{Tb}(1)-\mathrm{O}(8) \# 2$ & $53.1(2)$ & $\mathrm{O}(5) \# 5-\mathrm{Tb}(1)-\mathrm{O}(1) \# 3$ & $67.9(2)$ & $\mathrm{O}(6) \# 4-\mathrm{Tb}(1)-\mathrm{O}(1) \# 3$ & $67.4(2)$ \\
\hline $\mathrm{O}(10) \# 2-\mathrm{Tb}(1)-\mathrm{O}(8) \# 2$ & $70.3(2)$ & $\mathrm{O}(7) \# 2-\mathrm{Tb}(1)-\mathrm{O}(1) \# 3$ & $117.7(2)$ & $\mathrm{O}(9) \# 2-\mathrm{Tb}(1)-\mathrm{O}(1) \# 3$ & $123.2(2)$ \\
\hline $\mathrm{O}(9) \# 2-\mathrm{Tb}(1)-\mathrm{O}(8) \# 2$ & $89.8(2)$ & $\mathrm{O}(10) \# 2-\mathrm{Tb}(1)-\mathrm{O}(1) \# 3$ & $140.0(2)$ & $\mathrm{O}(1)-\mathrm{Tb}(1)-\mathrm{O}(1) \# 3$ & $78.3(2)$ \\
\hline $\mathrm{O}(3)-\operatorname{In}(1)-\mathrm{O}(3) \# 6$ & $92.3(9)$ & $\mathrm{O}(3)-\operatorname{In}(1)-\mathrm{O}(11) \# 7$ & $141.2(4)$ & $\mathrm{O}(11) \# 7-\operatorname{In}(1)-\mathrm{O}(12) \# 7$ & $55.5(3)$ \\
\hline $\mathrm{O}(3)-\operatorname{In}(1)-\mathrm{O}(4) \# 6$ & $89.0(6)$ & $\mathrm{O}(3) \# 6-\operatorname{In}(1)-\mathrm{O}(11) \# 7$ & $79.8(4)$ & $\mathrm{O}(3)-\operatorname{In}(1)-\mathrm{O}(12) \# 1$ & $94.7(6)$ \\
\hline $\mathrm{O}(3) \# 6-\operatorname{In}(1)-\mathrm{O}(4) \# 6$ & $58.1(4)$ & $\mathrm{O}(4) \# 6-\operatorname{In}(1)-\mathrm{O}(11) \# 7$ & $117.0(4)$ & $\mathrm{O}(3) \# 6-\operatorname{In}(1)-\mathrm{O}(12) \# 1$ & 163.1(4) \\
\hline $\mathrm{O}(3)-\operatorname{In}(1)-\mathrm{O}(4)$ & $58.1(4)$ & $\mathrm{O}(4)-\operatorname{In}(1)-\mathrm{O}(11) \# 7$ & $83.6(3)$ & $\mathrm{O}(4) \# 6-\operatorname{In}(1)-\mathrm{O}(12) \# 1$ & $137.3(4)$ \\
\hline $\mathrm{O}(3) \# 6-\operatorname{In}(1)-\mathrm{O}(4)$ & $89.0(6)$ & $\mathrm{O}(11) \# 1-\operatorname{In}(1)-\mathrm{O}(11) \# 7$ & $128.5(4)$ & $\mathrm{O}(4)-\mathrm{In}(1)-\mathrm{O}(12) \# 1$ & $81.8(5)$ \\
\hline $\mathrm{O}(4) \# 6-\operatorname{In}(1)-\mathrm{O}(4)$ & $133.6(7)$ & $\mathrm{O}(3)-\operatorname{In}(1)-\mathrm{O}(12) \# 7$ & $163.1(4)$ & $\mathrm{O}(11) \# 1-\operatorname{In}(1)-\mathrm{O}(12) \# 1$ & $55.5(3)$ \\
\hline $\mathrm{O}(3)-\operatorname{In}(1)-\mathrm{O}(11) \# 1$ & $79.8(4)$ & $\mathrm{O}(3) \# 6-\operatorname{In}(1)-\mathrm{O}(12) \# 7$ & $94.7(6)$ & $\mathrm{O}(11) \# 7-\operatorname{In}(1)-\mathrm{O}(12) \# 1$ & $85.1(3)$ \\
\hline
\end{tabular}




\begin{tabular}{|l|l|l|l|l|l|}
\hline $\mathrm{O}(3) \# 6-\operatorname{In}(1)-\mathrm{O}(11) \# 1$ & $141.2(4)$ & $\mathrm{O}(4) \# 6-\operatorname{In}(1)-\mathrm{O}(12) \# 7$ & $81.8(5)$ & $\mathrm{O}(12) \# 7-\operatorname{In}(1)-\mathrm{O}(12) \# 1$ & $82.8(7)$ \\
\hline $\mathrm{O}(4) \# 6-\operatorname{In}(1)-\mathrm{O}(11) \# 1$ & $83.6(3)$ & $\mathrm{O}(4)-\operatorname{In}(1)-\mathrm{O}(12) \# 7$ & $137.3(4)$ & $\mathrm{O}(11) \# 1-\operatorname{In}(1)-\mathrm{O}(12) \# 7$ & $85.1(3)$ \\
\hline $\mathrm{O}(4)-\operatorname{In}(1)-\mathrm{O}(11) \# 1$ & $117.0(4)$ & & & & \\
\hline
\end{tabular}


Table S3. Comparison of cycloaddition of $\mathrm{CO}_{2}$ with styrene oxide. ${ }^{a}$

\begin{tabular}{|c|c|c|c|}
\hline Entry & Catalyst & Yield $\%$ & Ref. \\
\hline 1 & InDCPN-Cl & 95 & S1 \\
\hline 2 & InDCPN-Br & 92 & S1 \\
\hline 3 & MOF-892 & 86 & S2 \\
\hline 4 & MOF-893 & 63 & S2 \\
\hline 5 & MOF-894 & 88 & S2 \\
\hline
\end{tabular}

${ }^{a}$ Reaction condition: in a typical reaction, styrene oxide $(20 \mathrm{mmol}), \mathrm{MOF} /$ catalyst $(1 \mathrm{~mol} \%), 1 \mathrm{~atm} \mathrm{CO}_{2}, \mathrm{TBAB}(5$ $\mathrm{mol} \%), 80^{\circ} \mathrm{C}$. 

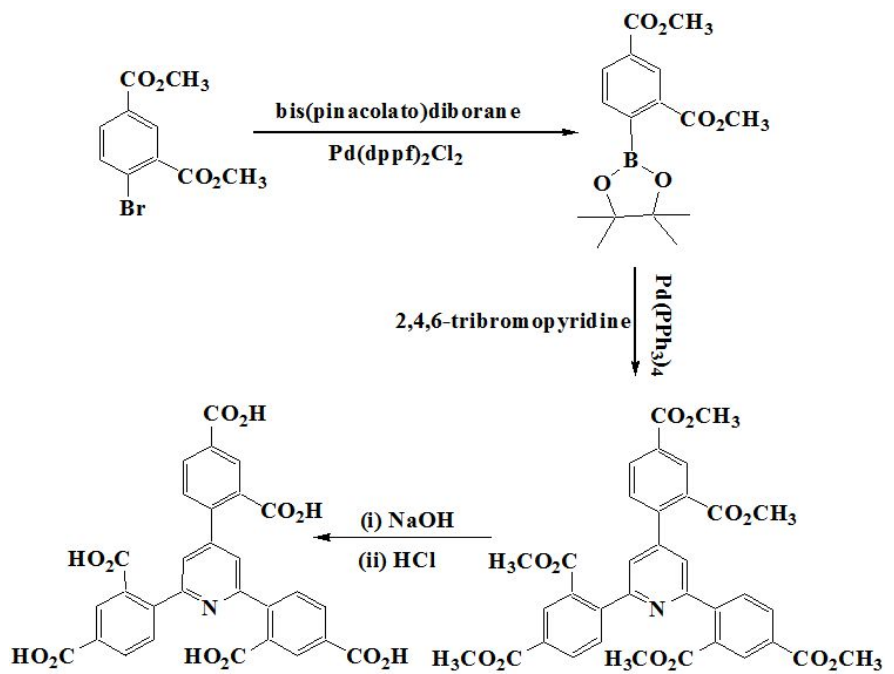

Scheme S1.The scheme for the synthesis of $\mathrm{H}_{6}$ TDP. 
Preparation of NUC-5. A mixture of $\mathrm{In}\left(\mathrm{NO}_{3}\right)_{3} \cdot 3 \mathrm{H}_{2} \mathrm{O}(0.10 \mathrm{mmol}, 35.5 \mathrm{mg}), \mathrm{Tb}\left(\mathrm{NO}_{3}\right)_{3} \cdot 6 \mathrm{H}_{2} \mathrm{O}(0.10 \mathrm{mmol}, 45.3 \mathrm{mg})$, and $\mathrm{H}_{6} \mathrm{TDP}(0.12 \mathrm{mmol}, 31.9 \mathrm{mg})$ was dissolved in $10 \mathrm{~mL}$ mixed solution of DMF and $\mathrm{H}_{2} \mathrm{O}(\mathrm{v}: \mathrm{v}=8: 2)$ followed by adding $0.3 \mathrm{~mL} 10 \% \mathrm{HNO}_{3}$ solution. After stirring for 30 minutes to make a homogeneous solution, the reaction mixture was sealed and heated in a $25 \mathrm{~mL}$ Teflon-lined stainless steel vessel at $110{ }^{\circ} \mathrm{C}$ for 4 days and then cooled to room temperature at a rate of $10^{\circ} \mathrm{C} / \mathrm{h}$. Block crystals of NUC- 5 were collected by filtration and washed by DMF/ $\mathrm{H}_{2} \mathrm{O}$ (3:1). (Yield: $64 \%$ based on $\left.\mathrm{H}_{6} \mathrm{TDP}\right)$. Anal. Calcd. for NUC-5 $\left(\mathrm{C}_{44} \mathrm{H}_{59} \mathrm{InN}_{2} \mathrm{O}_{23} \mathrm{~Tb}_{2}\right)$ : C, 41.80; $\mathrm{H}, 4.70 ; \mathrm{N}, 6.65(\%)$. Found: C, 42.13; H, 4.82; N, 6.34 (\%). IR (KBr pellet, $\mathrm{cm}^{-1}$ ): 3408 (vs), 1593 (vs), 1392 (vs), 1112 (w), 1019 (w), $782(\mathrm{~s}), 703(\mathrm{w}), 512(\mathrm{w})$.

X-ray crystallography. The diffraction intensity data for NUC-5 was obtained at 296(2) K using a Bruker SmartAPEX II CCD area detector (Mo-K $\alpha$ radiation, $\lambda=0.071073 \mathrm{~nm}$ ) with graphite-monochromated radiation. The reflection data were also corrected for empirical absorption corrections and Lorentz and polarization effects. The structures were solved by direct methods and refined by full-matrix least-squares using the SHELXL package. ${ }^{\text {S3-S6 }}$ All non-hydrogen atoms were refined anisotropically. Hydrogen atoms except those on water molecules were generated geometrically with fixed isotropic thermal parameters, and included in the structure factor calculations. The block of SQUEEZE in PLATON was employed to eliminate the highly disordered solvent molecular. The solvent content of NUC-5 was determined by the thermogravimetric analysis (Fig. S2) and elemental analysis.Crystallographic data and refinement parameter for NUC-5are given in Table S1. Selected bond lengths and angles for NUC-5 are listed in Table S2. Further details on the crystal structure investigations may be obtained from the Cambridge Crystallographic Data Centre, with the depository number CCDC-1980835 for NUC-5. 
(a)

a)
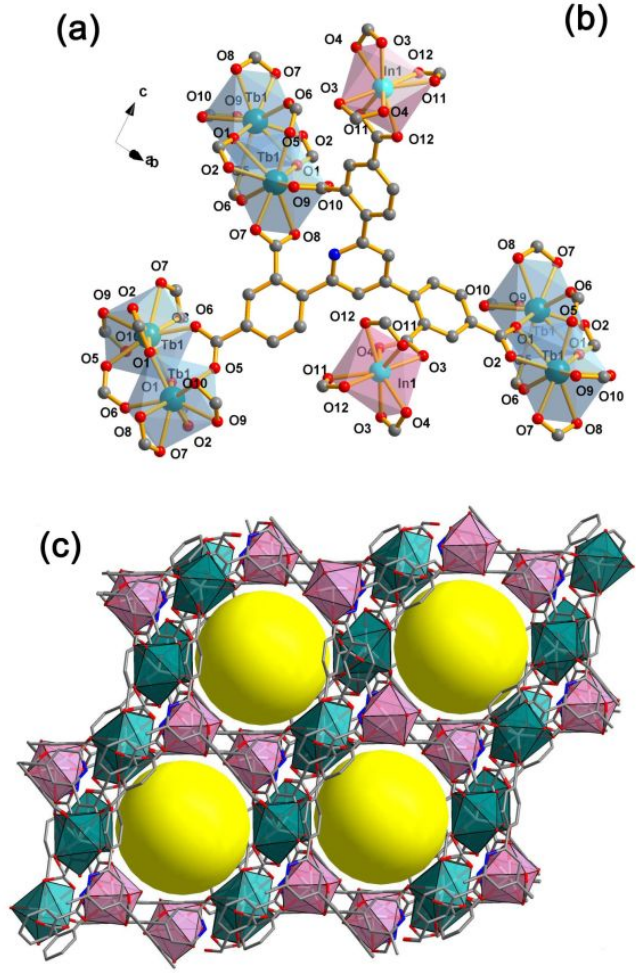

(b)
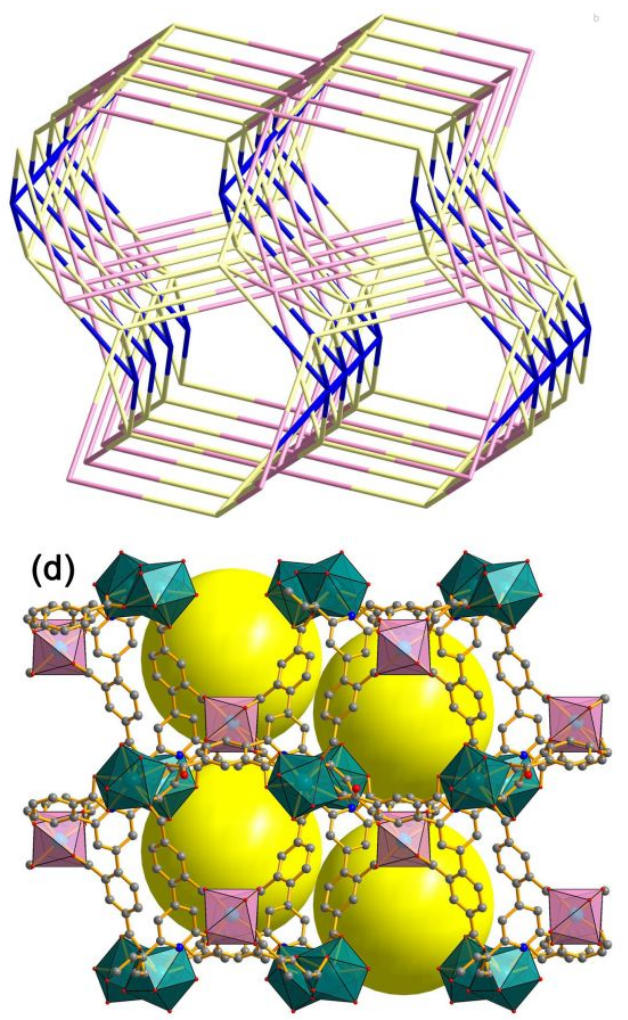

Figure S1. (a) The coordinationmode of HTDP ligand in NUC-5; (b) The 3D TAYZIC net with the point symbol being $\left\{4^{4} .6^{2}\right\}\left\{4^{5} .6^{5}\right\}_{2}\left\{4^{6} .6^{8} .8\right\}$; (c) The topology of NUC-5; (c) 1D channels with opening-node windows of and $12.1 \times 9.2 \AA^{2}$ viewed along [110]; (d) $1 \mathrm{D}$ channels with opening-node windows of $5.3 \times 6.8 \AA^{2}$ viewed along [100] axis. 


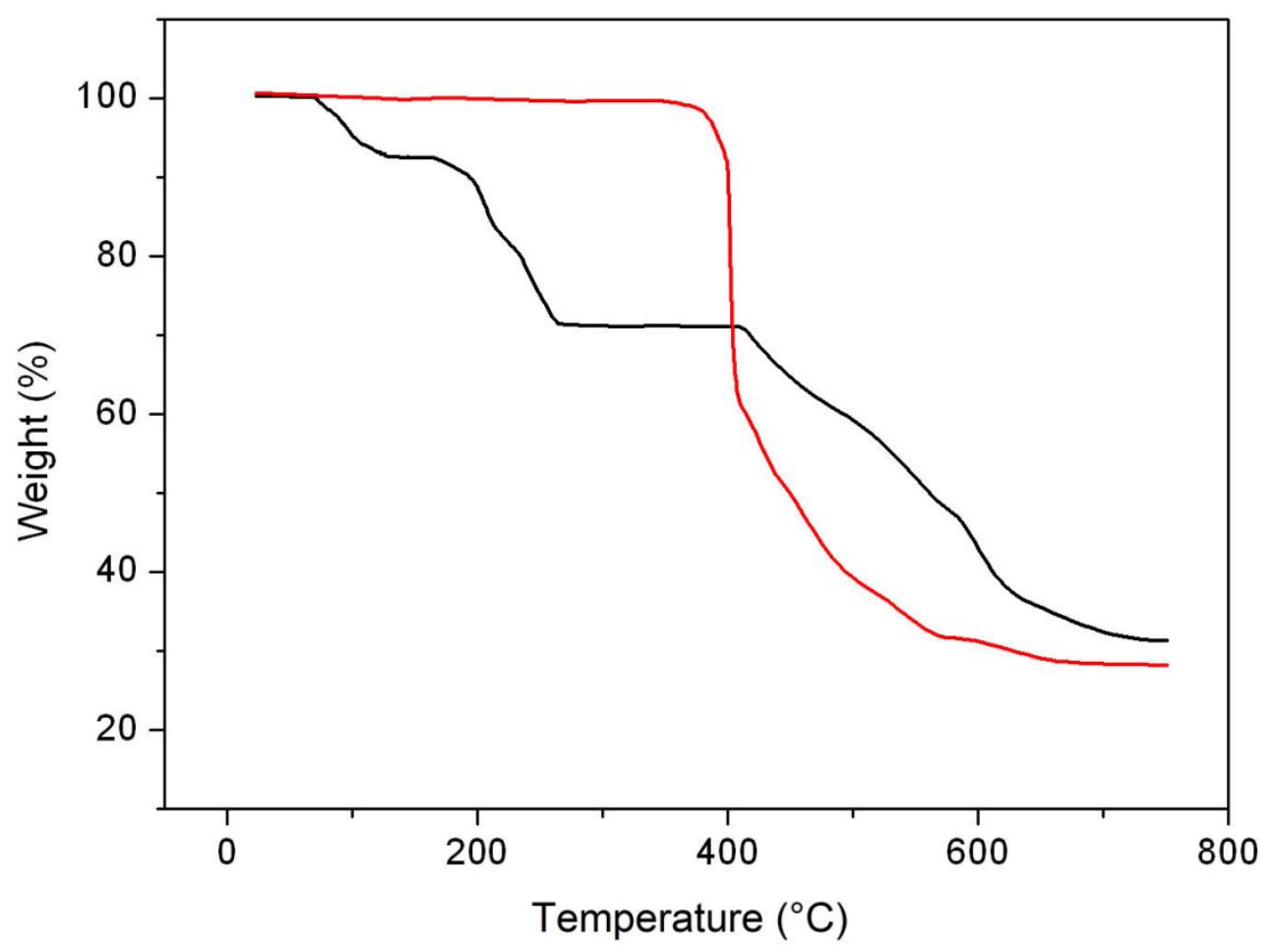

Figure S2. TGA curves of as-synthesized (black) and activated (red) sample of NUC-5. 


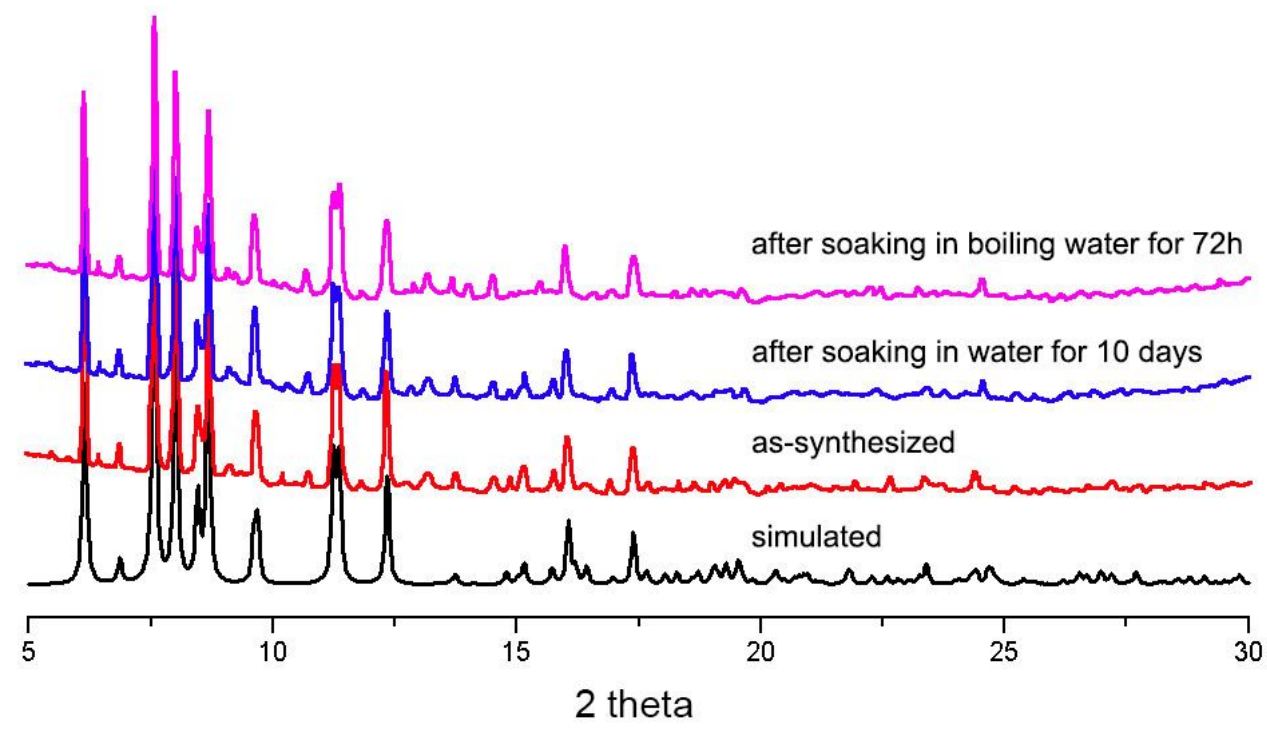

Figure S3. PXRD patterns of NUC-5 under water treatment. 


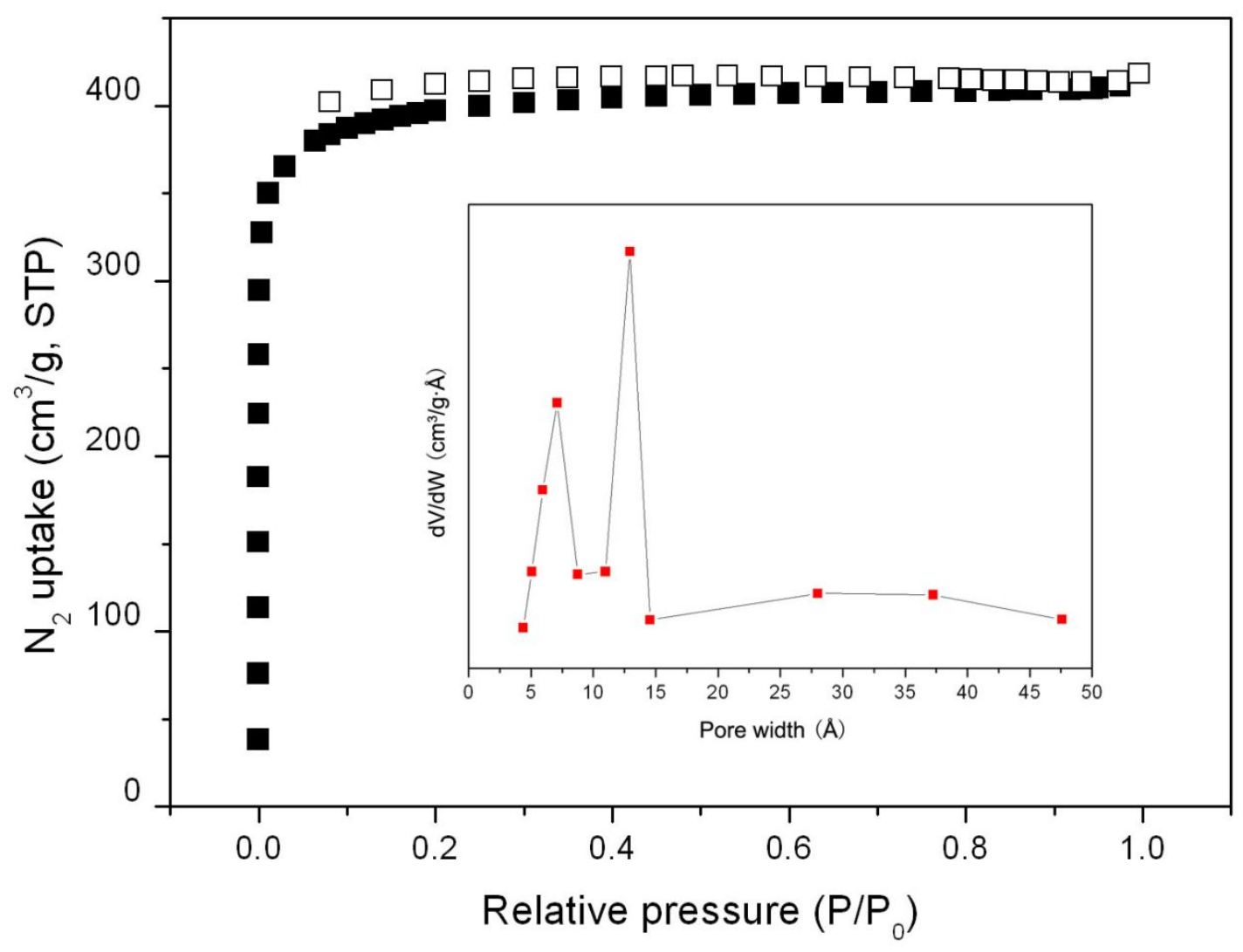

Figure S4. $\mathrm{N}_{2}$ absorption/desorption isotherms of NUC-5 at $77 \mathrm{~K}$ (Insert: the pore size distribution). 


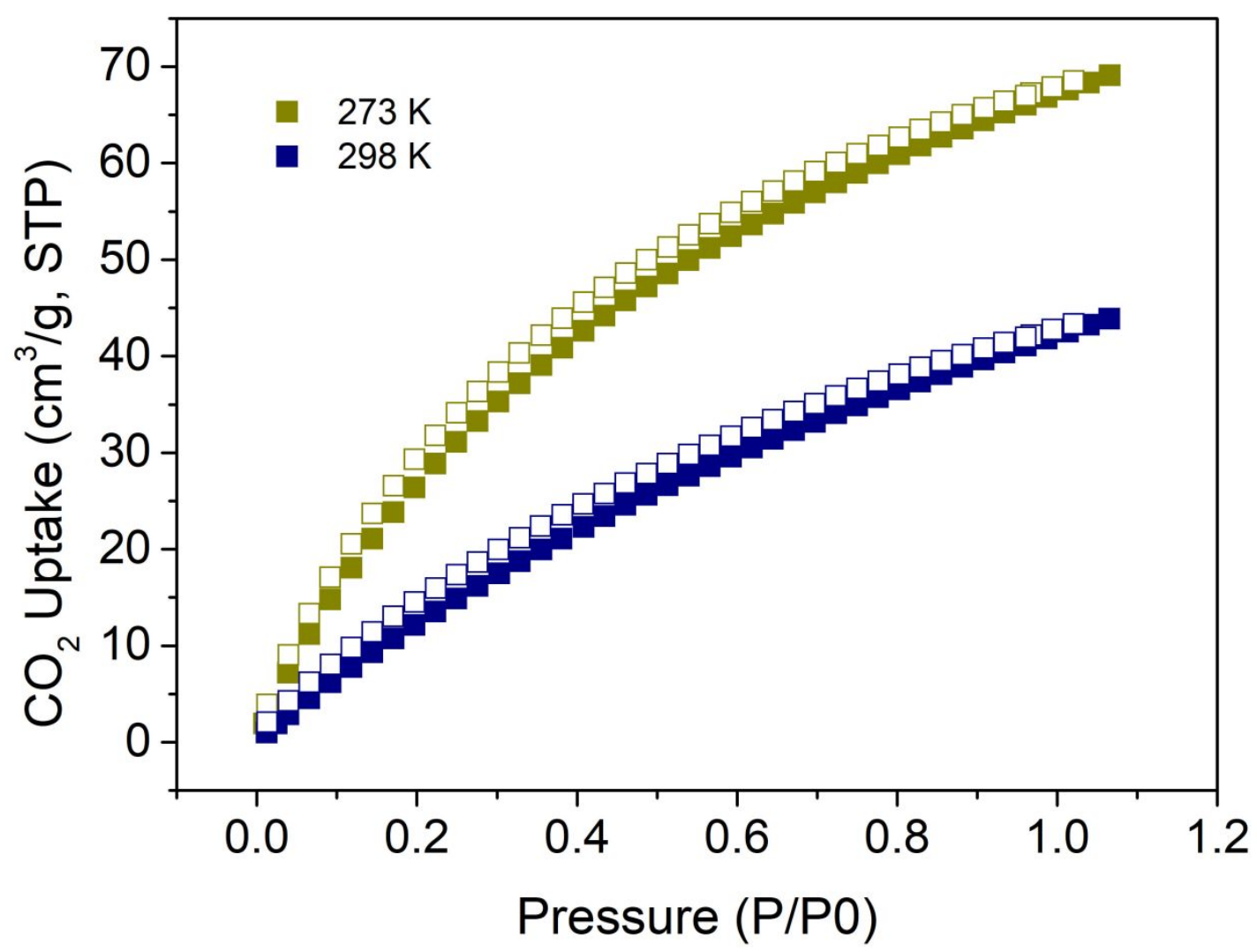

Figure S5. $\mathrm{CO}_{2}$ sorption isotherm of NUC-5 at 273 and $298 \mathrm{~K}$. 


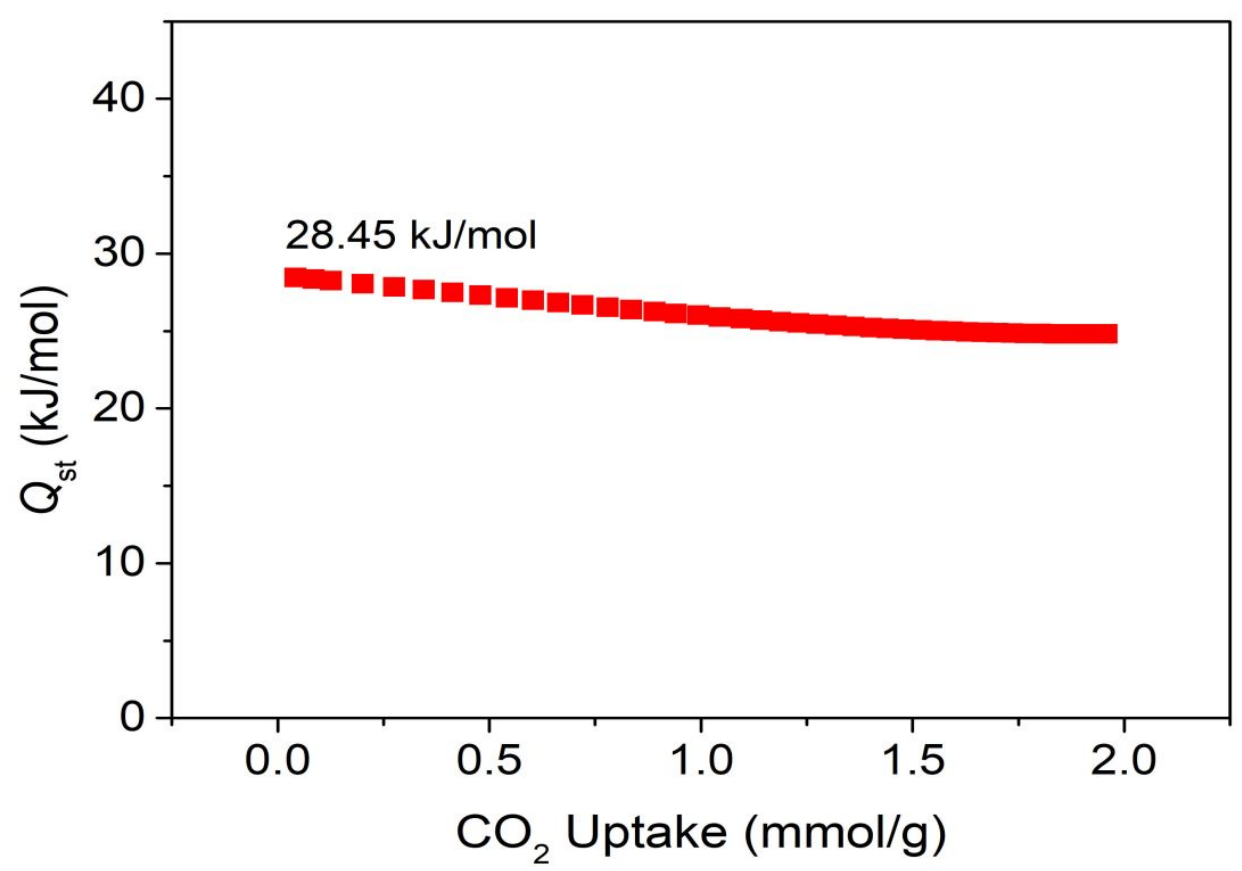

Figure S6. The adsorption heat of NUC-5 for $\mathrm{CO}_{2}$ 


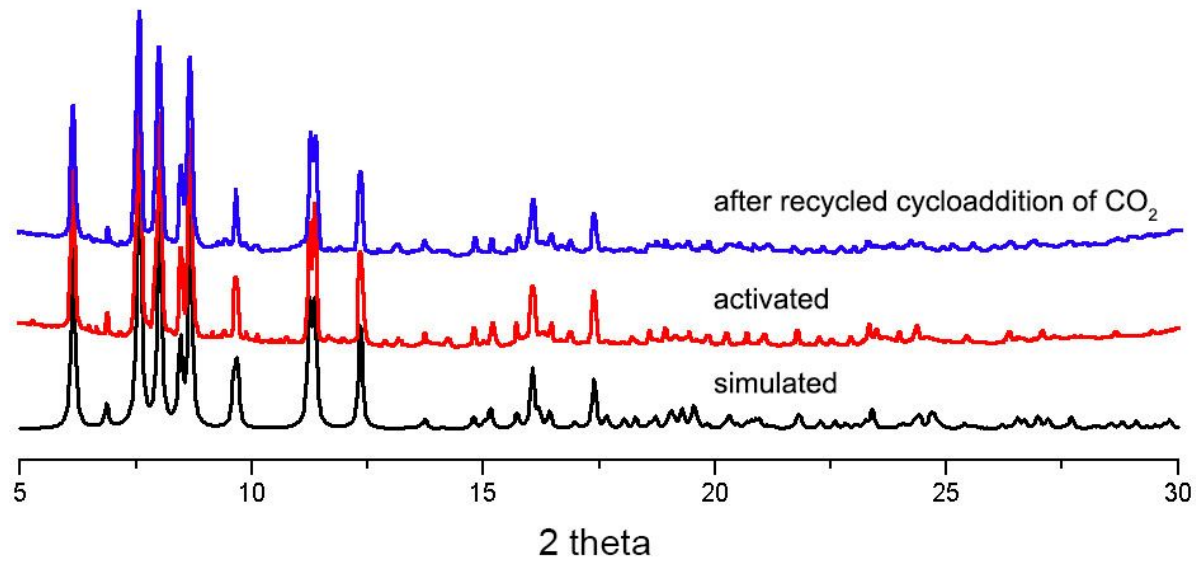

Figure S7. PXRD pattern of NUC-5 after recycled cycloaddition of $\mathrm{CO}_{2}$. 


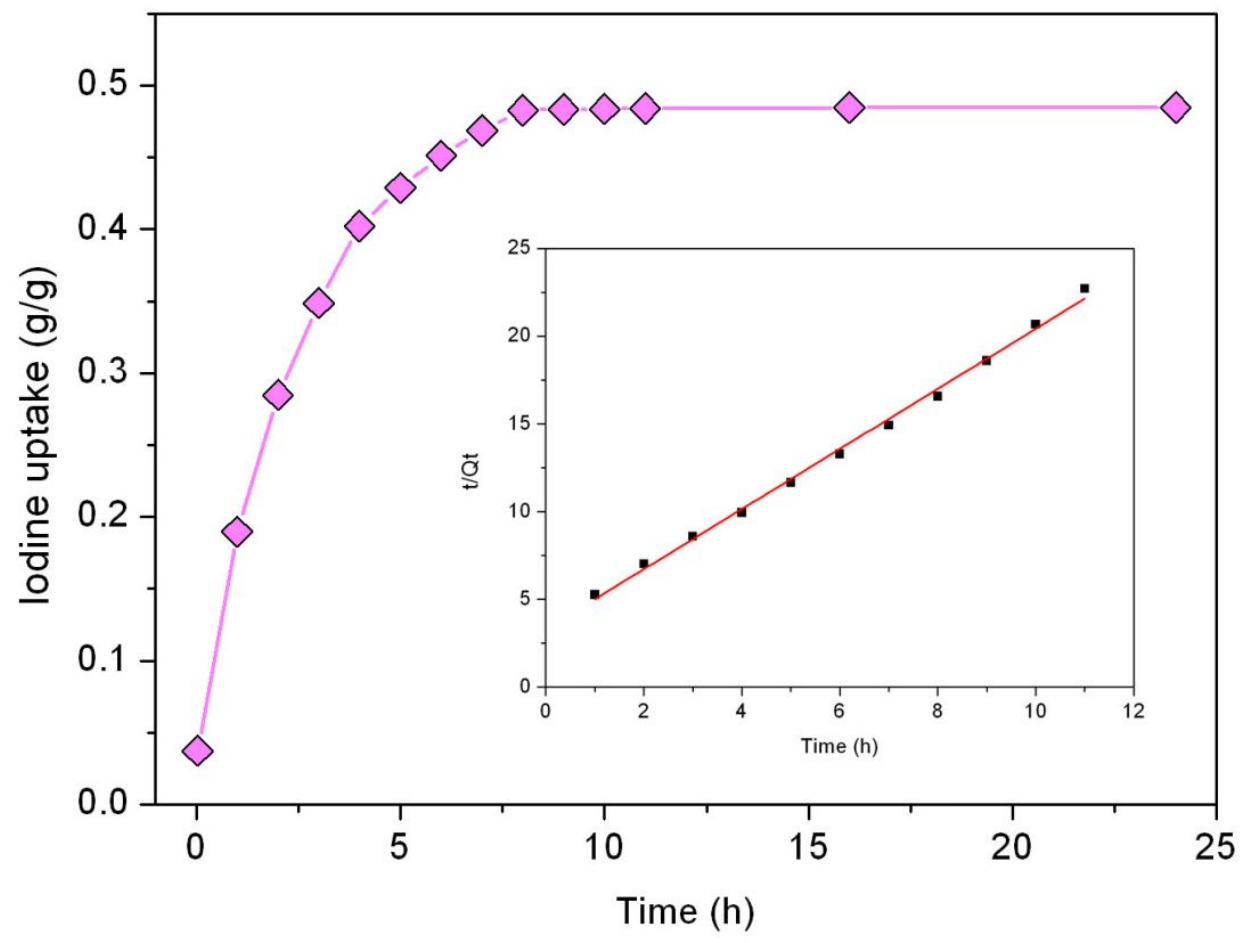

Figure S8. Kinetic studies of iodine sorptionin hexane solutionforNUC-5(insert:sorption kinetic fitted by the linear form of pseudo-second-order equation). 


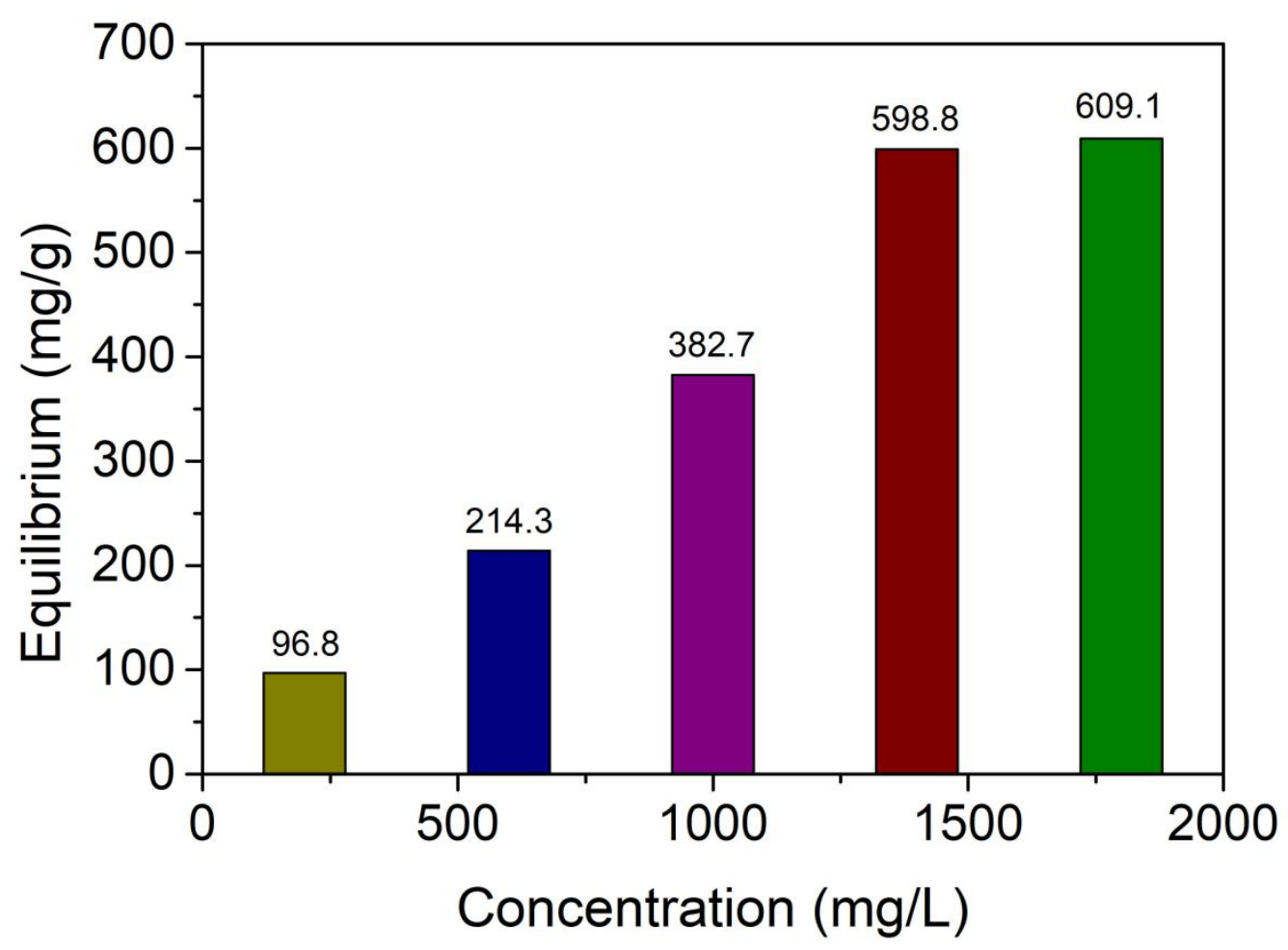

Fig. S9. The influence of initial concentrations on the adsorption of iodine by NUC-5. 


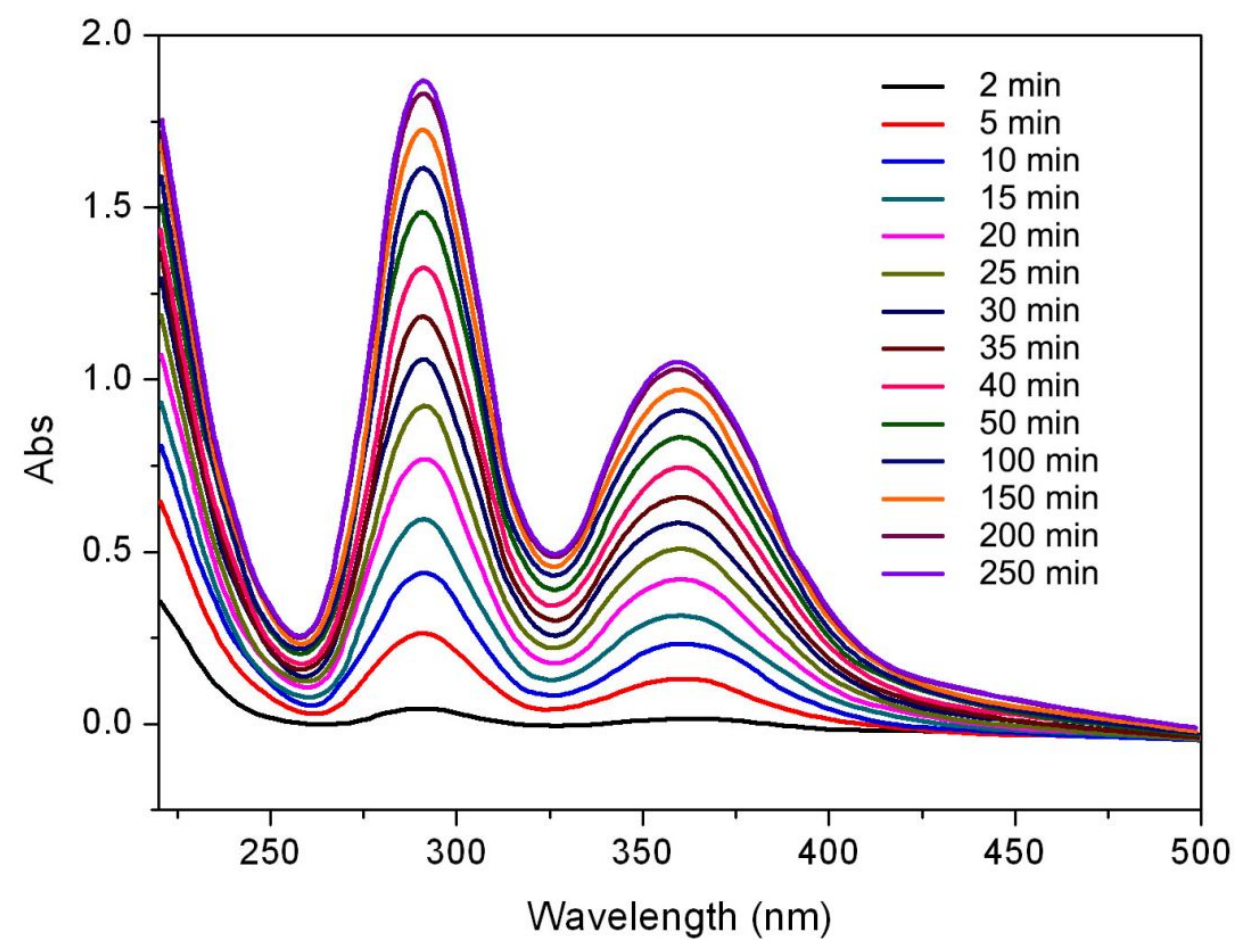

Figure S10. Time-dependentUV-vis spectra of iodine-loaded NUC-5 in ethanol. 


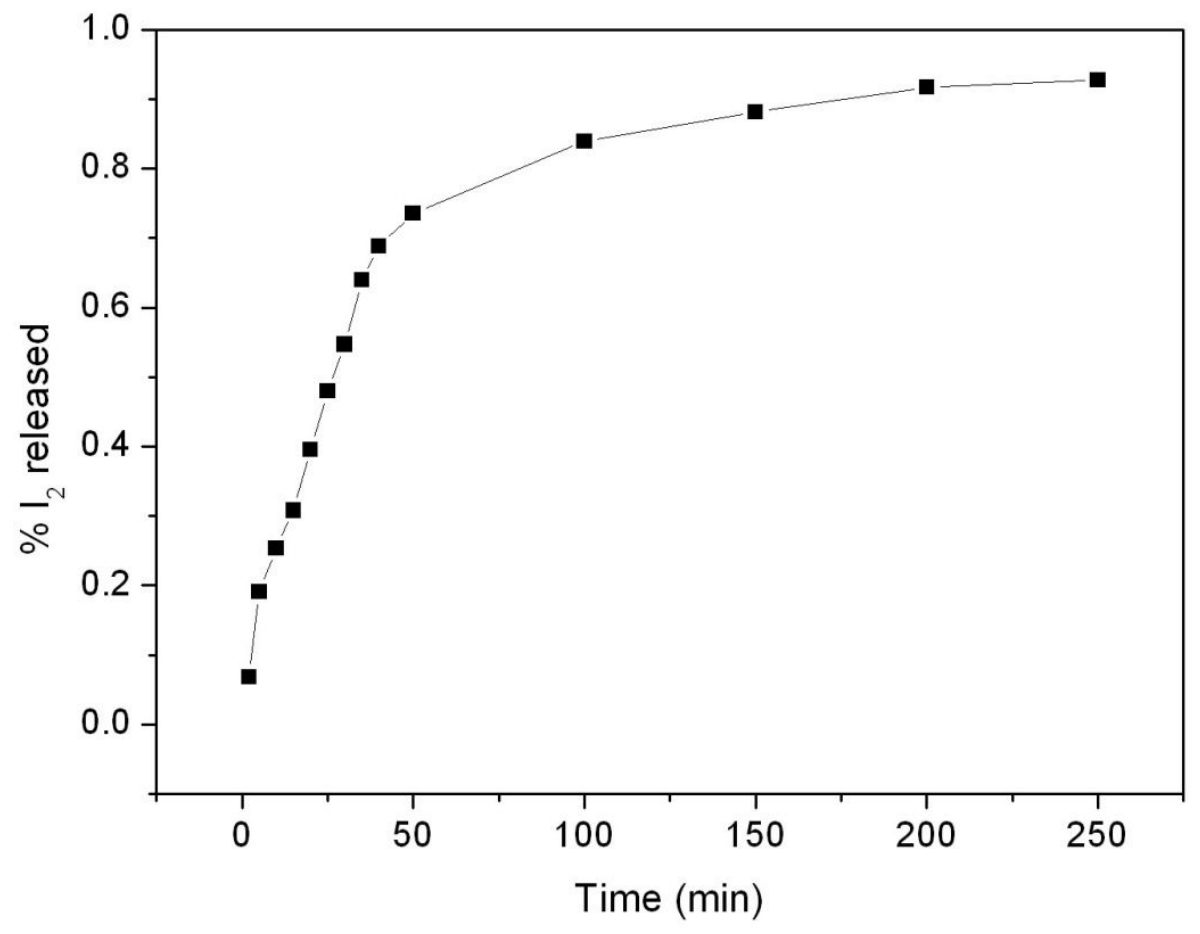

Figure S11. Kinetic studies of iodine release from iodine-loaded NUC-5 in ethanol. 


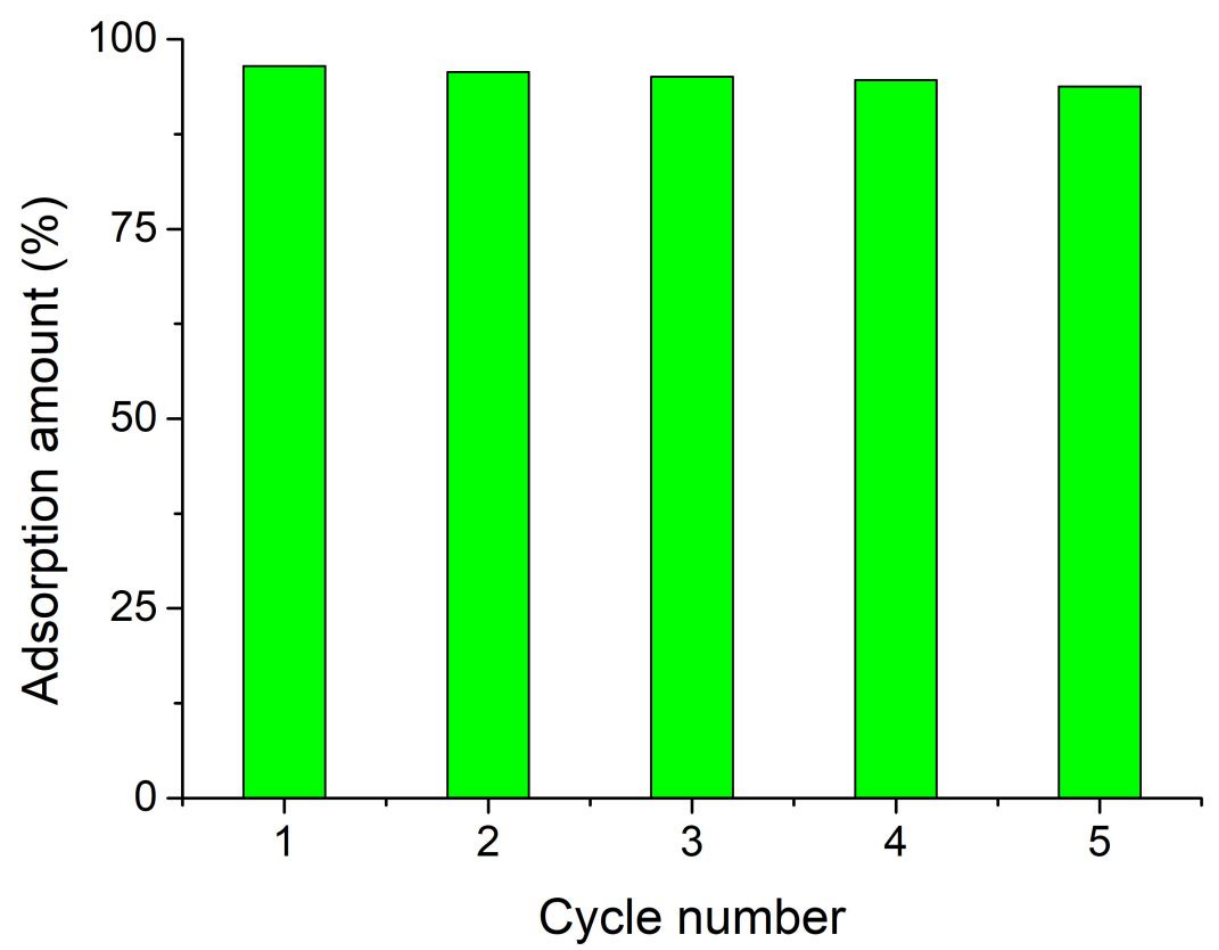

Figure S12. The recyclability experiment of NUC-5toward $\mathrm{I}_{2}$ upon five cycles. 


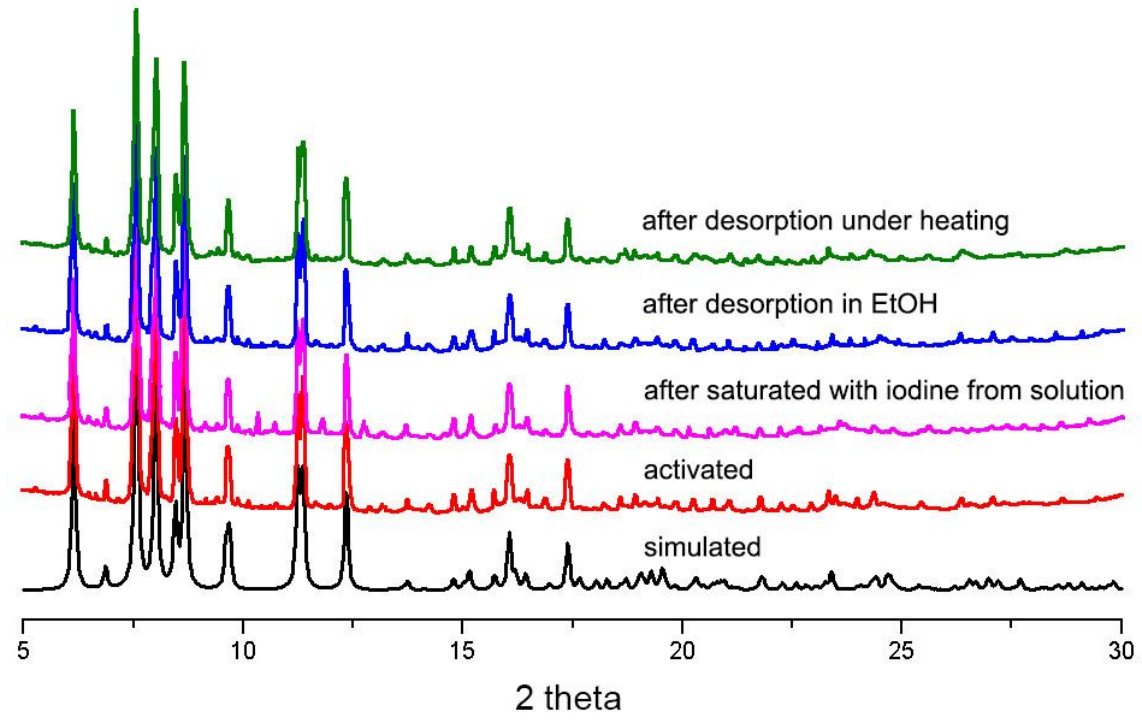

Figure S13. PXRD patterns of NUC-5. 


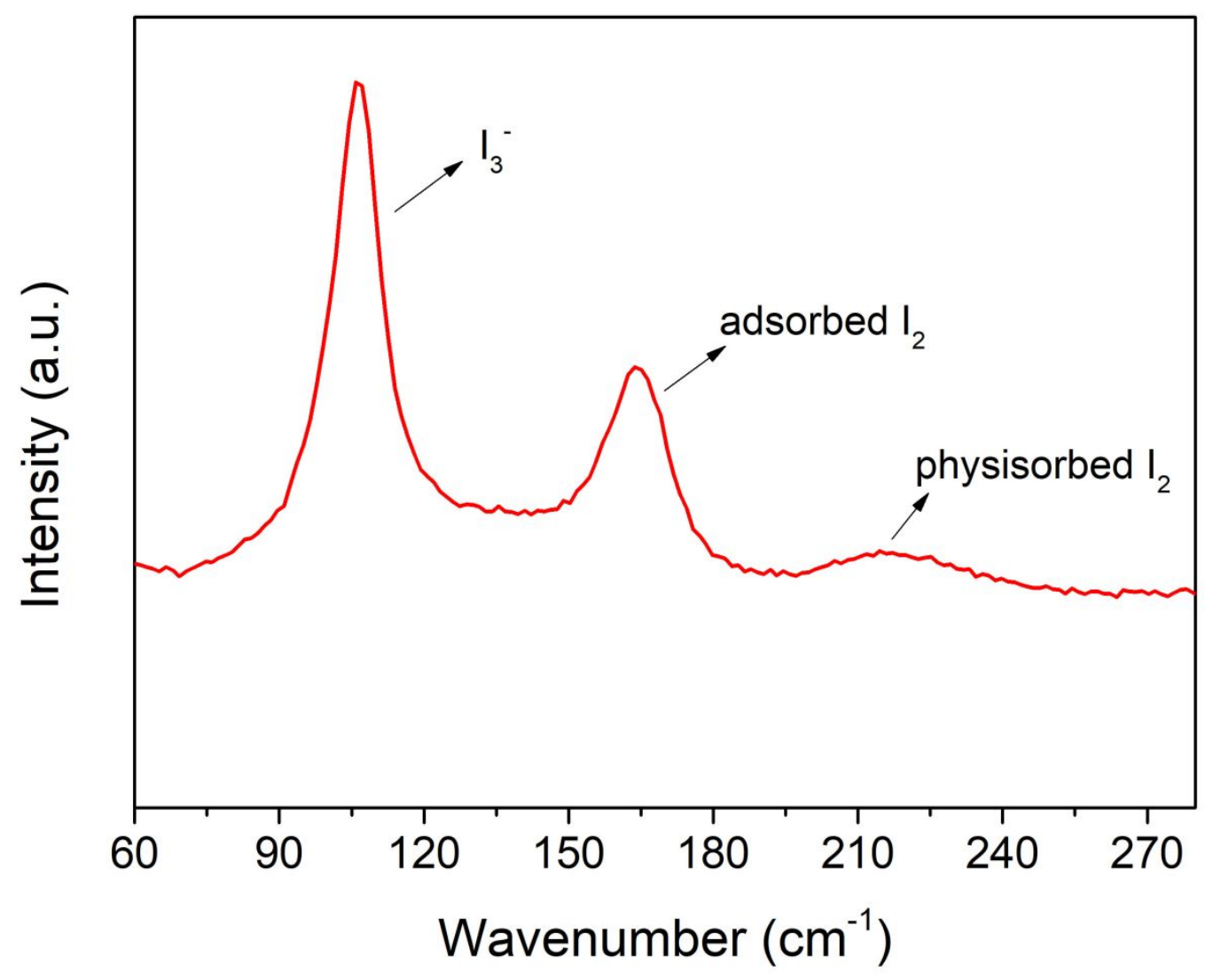

Figure S14. Raman spectra of I2@NUC-5 in the range of $60-270 \mathrm{~cm}^{-1}$. 


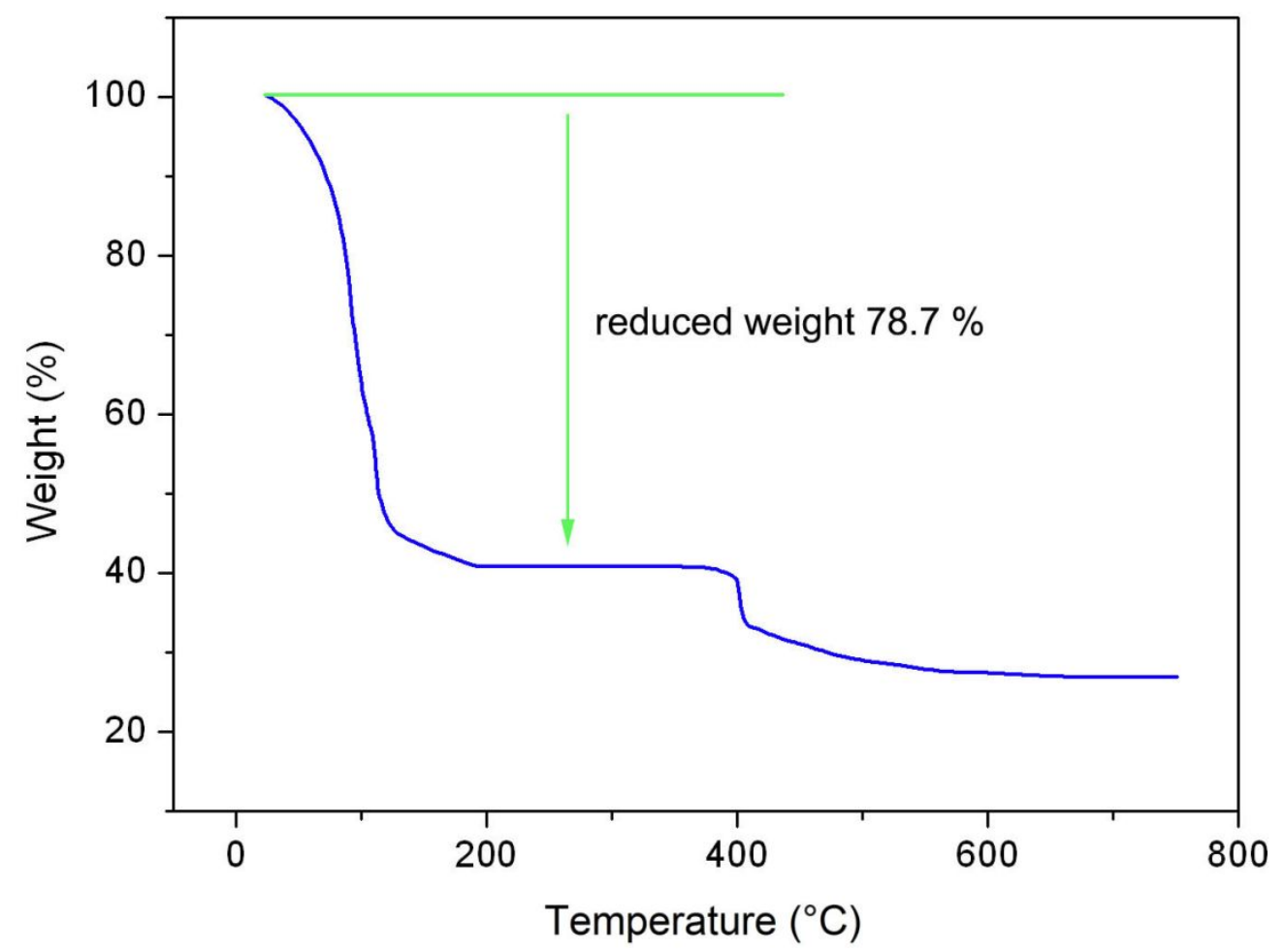

Figure $\mathrm{S} 15$. The TGA of $\mathrm{I}_{2} @$ NUC-5. 


\section{References}

S1. Yuan, Y.; Li, J.; Sun, X.; Li, G.; Liu, Y.; Verma, G.; Ma, S. Indium-Organic Frameworks Based on Dual Secondary Building Units Featuring Halogen-Decorated Channels for Highly Effective $\mathrm{CO}_{2}$ Fixation. Chem. Mater. 2019, 31, 1084-1091.

S2. Nguyen, P. T. K.; Nguyen, H. T. D.; Nguyen, H. N.; Trickett, C. A.; Ton, Q. T.; Gutiérrez-Puebla, E.; Monge, M. A.; Cordova, K. E.; Gándara, F. New Metal-Organic Frameworks for Chemical Fixation of $\mathrm{CO}_{2}$. ACS Appl. Mater. Interfaces 2018, 10, 733-744.

S3. Sheldrick, G. M. SHELXTL, version 5.1; Bruker Analytical X-ray Instruments Inc.: Madison, WI, 1998.

S4. Sheldrick, G. M. SHELX-97, PC Version; University of Gottingen: Gottingen, Germany, 1997.

S5. Blatov, V. A.; Shevchenko, A. P.; Serezhkin, V. N. J. Appl. Crystallogr. 2000, 33, 1193.

S6. Kuai, H. W.; Okamura, T. A.; Sun. W. Y. Polyhedron 2014, 72, 8-18. 